\title{
5-Demethoxyfumagillol, a Potent Angiogenesis Inhibitor Isolated from Aspergillus fumigatus
}

\author{
Deukjoon Kim, ${ }^{*, a}$ Jaeki Min, ${ }^{a}$ Soon Kil Ahn, ${ }^{b}$ Hong Woo LeE, ${ }^{b}$ Nam Song Chor, ${ }^{b}$ and \\ Seung Kee Moon ${ }^{b}$ \\ ${ }^{a}$ Research Institute of Pharmaceutical Sciences, College of Pharmacy, Seoul National University; San 56-1, Shillim-Dong, \\ Kwanak-Gu, Seoul 151-742, Korea: and ${ }^{b}$ New Drug Research Laboratories, Chong Kun Dang Research Institute; \\ Cheonan P.O. Box 74, Cheonan, 330-831, Korea. Received October 6, 2003; accepted December 1, 2003
}

A novel angiogenesis inhibitor, 5-demethoxyfumagillol (1), was obtained by isolation, purification and saponification of cultured broth of Aspergillus fumigatus. The structure was assigned as $(3 R, 4 R, 6 R)-4-[(2 R, 3 R)-2-$ methyl-3-(3-methyl-but-2-enyl)-oxiranyl]-1-oxa-spiro[2,5]octan-6-ol (1) by spectroscopic analysis and confirmed by independent synthesis from fumagillol (3). In addition, 6- $O$-(chloroacetylcarbamoyl)-5-demethoxyfumagillol (7) showed a potential anti-angiogenic activity in CAPE cells in vitro.

Key words 5-demethoxyfumagillol; angiogenesis inhibitor; Aspergillus fumigatus; fermentation; semi-synthetic fumagillol derivative

Angiogenesis, the phenomenon of generating a new capillary vessels, has a close connection with various diseases ${ }^{1)}$ such as the growth and transfer of solid cancer, rheumatoid arthritis, diabetic retinopathy, and psoriasis. In 1971, Judah Folkman of the Medical College of Harvard University, U.S.A., suggested the novel concept of treating solid tumors by inhibiting angiogenesis. ${ }^{2)}$ Recent clinical studies on antiangiogenic agents seem to indicate that the problem of tolerance associated with conventional anti-cancer agents could be alleviated, probably by acting directly on the endothelial cells rather than on tumor cells of a living organism.

Fifty years ago, Hanson and Eble reported that cultures of a fungus Aspergillus fumigatus (IMI-069714) inhibited Staphylococcus aureus 209 bacteriophage. 3) The structure and stereochemistry of the active constituent fumagillin was determined by X-ray crystallographic studies. ${ }^{4}$ Also, in 1990, Ingber et al. ${ }^{5)}$ reported that fumagillin (2) showed potent anti-angiogenic activity and inhibited endothelial cell proliferation in vitro and tumor-induced angiogenesis in vivo. ${ }^{6,7)}$ However, the effectiveness of $\mathbf{2}$ as an inhibitor of tumor growth was limited because it produced severe weight loss as a side effect. Ingber et al. started chemical modification of $\mathbf{2}$ in an effort to obtain analogues having the potent anti-angiogenic activity of $\mathbf{2}$ with less toxicity. As a result, one of the semi-synthetic derivatives, TNP-470 (4), has been found to have more potent anti-angiogenic activity and be less toxic compared to $2 .^{8-10)}$ TNP-470 (4) is currently one of the most promising small molecule inhibitors of angiogenesis and is being evaluated in phase III clinical trials as a potential anti-cancer drug. ${ }^{11-14)}$

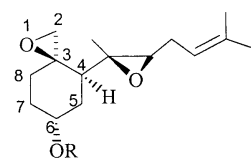

\footnotetext{
5-Demethoxyfumagillol (1) : $\mathrm{R}=\mathrm{H}$

6-O-(chloroacetylcarbamoyl)-

5-demethoxyfumagillol (7) : $\mathrm{R}=\mathrm{CONHCOCH}_{2} \mathrm{Cl}$
}

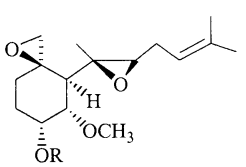

Fumagillin (2) : $\mathrm{R}=\mathrm{CO}\left(\mathrm{CH}^{t}=\mathrm{CH}\right)_{4} \mathrm{CO}_{2} \mathrm{H}$

Fumagillol (3) : $\mathrm{R}=\mathrm{H}$

TNP- $470(4): \mathrm{R}=\mathrm{CONHCOCH}_{2} \mathrm{Cl}$
In the course of our search for a new type of anti-angiogenesis inhibitors from cultured broths of soil microorganisms, 5-demethoxyfumagillol (1), a novel anti-angiogenic substance, was obtained by basic hydrolysis of 5-demethoxyfumagillin. ${ }^{15)}$

In the present paper, we describe the fermentation, isolation, and saponification of 5-demethoxyfumagillin, and structural assignment of $\mathbf{1}$ by spectroscopic analysis and independent synthesis (Chart 2). In addition, the preparation of a 5-demethoxyfumagillol analogue with a carbamoyl side chain and its anti-angiogenic activity are reported.

Chemistry To confirm the structure of 5-demethoxyfumagillol (1), semi-synthetic 1 was synthesized from fumagillol (3) as a starting material. First, oxidation of $\mathbf{3}$ by the Collins reagent, ${ }^{16}$ followed by reductive elimination of the resulting 6-ketofumagillol (5) by treatment with samarium(II) diiodide $\left(\mathrm{SmI}_{2}\right),{ }^{17)}$ produced the desired demethoxylated 6-ketofumagillol $\mathbf{6}$ in $50 \%$ yield. Then, stereoselective reduction of ketone 6 with L-selectride (lithium tri-sec-butylborohydride, $1.0 \mathrm{M}$ solution in tetrahydrofuran) furnished $83 \%$ yield of the desired 1 , along with $13 \%$ of epimeric $6-$ epi-5-demethoxyfumagillol $\left(\mathbf{1}^{\prime}\right)$. Finally, in order to examine the anti-angiogenic activities of demethoxyfumagillol derivatives, we attempted chemical modification of 1. 6-O(Chloroacetylcarbamoyl)-5-demethoxyfumagillol (7) was obtained by treatment of $\mathbf{1}$ with chloroacetyl isocyanate in the presence of a stoichiometric amount of DMAP in dichloromethane in $70 \%$ yield (Chart 2 ).

\section{Results and Discussion}

Several types of angiogenesis inhibitors such as angiostatic steroids, ${ }^{18)}$ retinoid ${ }^{19)}$ and cartilage factors ${ }^{20)}$ have been discovered, although they are not clinically useful due to toxicity and potency. Therefore, it is of interest to search for new types of angiogenesis inhibitors.

In the course of our extensive screening program for novel angiogenesis inhibitors from soil microorganisms, we found that a novel 5-demethoxyfumagillol (1), produced by the saponification of 5-demethoxyfumagillin isolated from the cultured broth of Aspergillus fumigatus (IMI-069714), showed potent anti-proliferation activity against calf pul- 


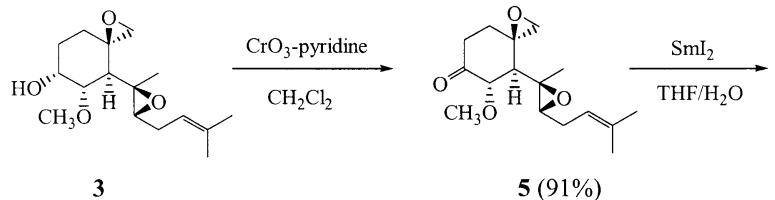<smiles>CC(C)=CCCC1(C)OCCC1(C)C1CC(O)CCC1=O</smiles><smiles>CC(C)=CCC1(C)OCCC1(C)C(=O)OC(=O)NC(=O)CCl</smiles>

Chart 2

monary artery endothelial (CPAE) cells. Spectral data for 5demethoxy fumagillin were very similar to those of known fumagillin (2) except for the 5-methoxy moiety. Saponification of 5-demethoxyfumagillin to remove the polyene moiety gave the corresponding 5-demethoxyfumagillol (1) in $48 \%$ yield. The structure of $\mathbf{1}$, a basic hydrolysate, was established by an extensive spectroscopic analysis of NMR $\left({ }^{1} \mathrm{H},{ }^{13} \mathrm{C}\right)$, FTIR, and HR-Mass (fast atom bombardment, FAB).

In order to definitively confirm the structure of 5demethoxyfumagillol (1), semi-synthetic compound $\mathbf{1}$ was independently prepared from fumagillol (3) as previously described in Chart 2. Thus, the structure of 5-demethoxyfumagillol (1) was elucidated to be $(3 R, 4 R, 6 R)-4-[(2 R, 3 R)-2-$ methyl-3-(3-methyl-but-2-enyl)-oxiranyl]-1-oxa-spiro[2,5]octan-6-ol.

In order to examine the in vitro inhibitory activity of $\mathbf{1}$ and its derivative against endothelial cell proliferation, chemical modification of $\mathbf{1}$ was carried out. Chemical modification of 1 gave 6-O-(chloroacetylcarbamoyl)-5-demethoxyfumagillol (7) using chloroacetyl isocyanate in the presence of DMAP as a representative compound. The anti-proliferation activity and cytotoxicity of a novel $\mathbf{1}$ and $\mathbf{7}$ were examined in CPAE cells and lymphoma (L5178Y, mice) cells, respectively. The anti-proliferation activity of $\mathbf{1}$ was very similar to that of $\mathbf{3}$, whereas 7 showed at least eight times more potent anti-proliferation activity compared to $\mathbf{7}$, as described in Table 1 . However, both 1 and its carbamoyl derivative 7, exhibited less potent activity compared to TNP-470. Taking into consideration these results, the methoxy moiety on the 5-position of fumagillol compounds seems to be necessary and important for the anti-proliferation activity.

Currently, efforts are under way to elucidate the structure-activity relationship of these fumagillin analogues as potential anti-cancer agents.

\section{Experimental}

All reactions were conducted under anhydrous conditions in solvents dried over molecular sieves type $4 \AA$ under a nitrogen atmosphere and performed using oven dried glassware. Melting points were determined on a
Table 1. Anti-proliferation Activity of Fumagillol and Demethoxyfumagillol Analogues

Compound

a) The preparation of reference compound (4) was carried out following reported procedure. ${ }^{21}$ b) Anti-proliferation activities were colorimetrically measured by SBR (CPAE cell) and MTT (L5178Y) method and $\mathrm{IC}_{50}$ values were estimated by Probits method (Pharm/PCS ${ }^{\mathrm{R}}$ ).

Buchi 510 capillary apparatus and are uncorrected. IR spectra were recorded on a Bruker Vector 22 FT-IR spectrometer. NMR spectra were recorded on a Bruker DPX $400 \mathrm{MHz}$ instrument and performed in $\mathrm{CDCl}_{3}$ using tetramethylsilane as the internal reference except where indicated otherwise. The coupling constants $(J)$ are reported in Hz. Mass spectra were recorded on a HP 5989B mass spectrometer. Flash chromatography was performed using Merck silica gel $60(230-400$ mesh $)$ according to the procedure reported previously. ${ }^{22)}$

Preparation of 5-Demethoxyfumagillol by Fermentation. Fermentation A suspension of spores $\left[1.0 \times 10^{3}\right.$ spores $/ \mathrm{ml}, 10 \%$ glycerol, $1 \%$ Tween 80, 5\% lactose (w/v)] of Aspergillus fumigatus (IMI-069714) was inoculated in pre-culture medium (CSL $40 \mathrm{~g} / 1$, glucose $30 \mathrm{~g} / 1, \mathrm{CaCO}_{3} 10 \mathrm{~g} / 1$ ) in a concentration of $1 \%(\mathrm{v} / \mathrm{v})$, and cultured with rotary shaking at $28^{\circ} \mathrm{C}$. After $30 \mathrm{~h}$ the pre-culture was inoculated in a 2501 jar fermentor containing 181 of culture medium (CSL $50 \mathrm{~g} / 1$, glucose $30 \mathrm{~g} / 1, \mathrm{CaCO}_{3} 10 \mathrm{~g} / \mathrm{l}$ ) in a concentration of $1 \%$, and cultured at $28^{\circ} \mathrm{C}$ for $60-70 \mathrm{~h}$.

Isolation of 5-Demethoxyfumagillin The culture was filtered through a filter paper, and the filtrate (about 1.11) was applied to a HP-20 column to adsorb the active material. The HP-20 column was washed with $50 \mathrm{ml}$ of $50 \%$ aqueous methanol and eluted with $50 \mathrm{ml}$ of methanol/ethanol $(1: 1$, $\mathrm{v} / \mathrm{v})$ solution. The active portions were combined and concentrated under reduced pressure. A proper amount of chloroform was added to dissolve the residue. The same amount of distilled water was added to the chloroform solution and the mixture was centrifuged to separate the chloroform layer and the layer was concentrated under reduced pressure. About $9 \mathrm{~g}$ of the concentrate was adsorbed on a silica gel column of $9 \mathrm{~g}$ volume and the column was eluted with a mixed solvent of chloroform/methanol/acetic acid (100:5:0.1, $\mathrm{v} / \mathrm{v})$. The active portions were combined and concentrated under reduced pressure (about $150 \mathrm{mg}$ ) and the residue was dissolved in a small amount of ethyl acetate. The solution was left overnight at $-20^{\circ} \mathrm{C}$ to induce precipitation. The precipitated material $(120 \mathrm{mg})$ containing fumagillin was washed with cold ethyl acetate $2-3$ times to obtain a mixed sample having high purity. The mixture was separated by medium pressure liquid chromatography (MPLC) with dichloromethane/methanol $(98: 2, \mathrm{v} / \mathrm{v})$ as elution solvent to give the crude title compound 5-demethoxyfumagillin as an off-white foam product (6.5 mg, 35.5\% yield). IR (neat) $v_{\max } \mathrm{cm}^{-1}: 3855,3647,3510,2920$, 1695, 1680, 1650, 1628, 1537, 1520, 1362, 1080. ${ }^{1} \mathrm{H}-\mathrm{NMR}$ (400 MHz, 
$\left.\mathrm{CDCl}_{3}\right) \delta: 7.33-7.21(\mathrm{~m}, 2 \mathrm{H}), 6.64-6.59(\mathrm{~m}, 2 \mathrm{H}), 6.51-6.46(\mathrm{~m}, 2 \mathrm{H})$, 5.95 (dd, $J=4.04,15.3 \mathrm{~Hz}, 2 \mathrm{H}), 5.36$ (br s, $1 \mathrm{H}), 5.19$ (t, $J=7.54 \mathrm{~Hz}, 1 \mathrm{H}$ ), $2.91(\mathrm{~d}, J=4.36 \mathrm{~Hz}, 1 \mathrm{H}), 2.45-2.35(\mathrm{~m}, 1 \mathrm{H}), 2.17-1.79(\mathrm{~m}, 7 \mathrm{H}), 1.75(\mathrm{~s}$, $3 \mathrm{H}), 1.66(\mathrm{~s}, 3 \mathrm{H}), 1.15(\mathrm{~s}, 3 \mathrm{H}), 0.93-0.88(\mathrm{~m}, 1 \mathrm{H})$.

Preparation of 5-Demethoxyfumagillol (1) To 5-demethoxyfumagillin $(6 \mathrm{mg}), 0.1 \mathrm{~N} \mathrm{NaOH}$ solution $(0.6 \mathrm{ml})$ was added and the mixture was stirred at room temperature for $6 \mathrm{~h}$. The reaction mixture was diluted with ethyl ether $(2.5 \mathrm{ml})$, and the organic layer was separated and washed with water $(1 \mathrm{ml})$ and brine $(1 \mathrm{ml})$, and dried over anhydrous magnesium sulfate. After filtering, the filtrate was concentrated by evaporation under reduced pressure. The obtained residue was purified by silica gel column chromatography with ethyl acetate $/ n$-hexane $(1: 1, \mathrm{v} / \mathrm{v})$ to obtain the title compound, 5demethoxyfumagillol (1) as a colorless oil $(2.5 \mathrm{mg}, 48 \%$ yield). IR (neat) $v_{\max } \mathrm{cm}^{-1}: 3850,3732,3647,3440,2920,1698,1680,1652,1558,1507$, 1460, 1382, 980. ${ }^{1} \mathrm{H}-\mathrm{NMR}\left(400 \mathrm{MHz}, \mathrm{CDCl}_{3}\right) \delta: 5.19-5.15(\mathrm{~m}, 1 \mathrm{H})$, $4.31-4.29(\mathrm{~m}, 1 \mathrm{H}), 2.86(\mathrm{~d}, J=4.4 \mathrm{~Hz}, 1 \mathrm{H}), 2.39(\mathrm{~m}, 1 \mathrm{H}), 2.42-2.33(\mathrm{~m}$, $1 \mathrm{H}), 2.27-1.78(\mathrm{~m}, 1 \mathrm{H}), 1.74(\mathrm{~s}, 3 \mathrm{H}), 1.65(\mathrm{~s}, 3 \mathrm{H}), 1.14(\mathrm{~s}, 3 \mathrm{H}), 1.12-$ $1.03(\mathrm{~m}, 1 \mathrm{H})$.

Semi-synthetic Procedure for 5-Demethoxyfumagillol (1) and 6-O(Chloroacethylcarbamoyl)-5-demethoxyfumagillol (7). (3R,4R,5S)-5Methoxy-4-[(2R,3R)-2-methyl-3-(3-methyl-but-2-enyl)-oxiranyl]-1-oxaspiro[2.5]octan-6-one (5) To a solution of pyridine $(1.0 \mathrm{ml})$ in dry dichloromethane $(14 \mathrm{ml})$ at room temperature was added chromium(VI) oxide $(420 \mathrm{mg})$. After stirring for $30 \mathrm{~min}$ at the same temperature, a solution of fumagillol $3(200 \mathrm{mg}, 0.71 \mathrm{mmol})$ in dry dichloromethane $(7 \mathrm{ml})$ was added dropwise and the resulting mixture was stirred at room temperature for $6 \mathrm{~h}$ under $\mathrm{N}_{2}$ atmosphere. The reaction mixture was filtered through celite to remove residual chromium. The filtrate was concentrated in vacuo to leave a pale yellowish oil which was purified by column chromatography on $\mathrm{SiO}_{2}$ with ethyl acetate/ $n$-hexane $(1: 4, \mathrm{v} / \mathrm{v})$ to give the title oxidized ketofumagillol compound $\mathbf{5}$ as a colorless oil (180 mg, 91\% yield). IR (neat) $v_{\max } \mathrm{cm}^{-1}: 2917,1730,1558,1455,1114,457,418 \mathrm{~cm}^{-1} .{ }^{1} \mathrm{H}-\mathrm{NMR}$ $\left(400 \mathrm{MHz}, \mathrm{CDCl}_{3}\right) \delta: 5.19(\mathrm{t}, J=7.5 \mathrm{~Hz}, 1 \mathrm{H}), 4.08(\mathrm{~d}, J=10.3 \mathrm{~Hz}, 1 \mathrm{H}), 3.51$ $(\mathrm{s}, 3 \mathrm{H}), 3.06(\mathrm{~d}, J=4.3 \mathrm{~Hz}, 1 \mathrm{H}), 2.73(\mathrm{~d}, J=4.3 \mathrm{~Hz}, 1 \mathrm{H}), 2.72-2.65(\mathrm{~m}$, $1 \mathrm{H}), 2.60(\mathrm{t}, J=6.4 \mathrm{~Hz}, 1 \mathrm{H}), 2.52(\mathrm{dt}, J=14.0,4.3 \mathrm{~Hz}, 1 \mathrm{H}), 2.42-2.37(\mathrm{~m}$, $1 \mathrm{H}), 2.18-2.12(\mathrm{~m}, 1 \mathrm{H}), 2.06(\mathrm{td}, J=13.6,5.4 \mathrm{~Hz}, 1 \mathrm{H}), 1.88(\mathrm{~d}, J=10.5 \mathrm{~Hz}$, $1 \mathrm{H}), 1.75(\mathrm{~s}, 3 \mathrm{H}), 1.73-1.69(\mathrm{~m}, 1 \mathrm{H}), 1.65(\mathrm{~s}, 3 \mathrm{H}), 1.29(\mathrm{~s}, 3 \mathrm{H}) ;{ }^{13} \mathrm{C}-\mathrm{NMR}$ $\left(\mathrm{CDCl}_{3}, 100 \mathrm{MHz}\right) \delta: 207.14,135.11,118.28,83.25,60.52,58.67,58.60$, 58.49, 53.66, 51.86, 36.87, 33.27, 27.42, 25.76, 18.02, 13.92. HR-MS m/z: Calcd for $\mathrm{C}_{16} \mathrm{H}_{24} \mathrm{O}_{4}\left(\mathrm{M}^{+}\right)$, 280.1675. Found: 280.1666 .

$(3 R, 4 R)-4-[(2 R, 3 R)$-2-Methyl-3-(3-methyl-but-2-enyl)-oxiranyl]-1-oxa spiro[2.5]octan-6-one (6) To a pre-cooled $\left(-78^{\circ} \mathrm{C}\right)$ and stirred solution of 6-ketofumagillol compound $5(135 \mathrm{mg}, 0.48 \mathrm{mmol})$ in $\mathrm{THF} / \mathrm{H}_{2} \mathrm{O}(10: 1$, $\mathrm{v} / \mathrm{v}, 15 \mathrm{ml})$ was added $0.1 \mathrm{M} \mathrm{SmI}_{2}$ solution in tetrahydrofuran $(9.6 \mathrm{ml}$, $0.96 \mathrm{mmol}$ ) with a syringe pump under $\mathrm{N}_{2}$ atmosphere. The resultant dark blue mixture was stirred at the same temperature for $30 \mathrm{~min}$, and then allowed to warm to room temperature for $4 \mathrm{~h}$. The reaction mixture was poured into saturated aqueous $\mathrm{K}_{2} \mathrm{CO}_{3}(50 \mathrm{ml})$ and extracted with ethyl acetate $(3 \times 25 \mathrm{ml})$. The combined organic layer was washed with water $(50 \mathrm{ml})$, dried over anhydrous $\mathrm{MgSO}_{4}$, filtered, and concentrated in vacuo and purified by column chromatography on silica gel with ethyl acetate $/ n$ hexane $(1: 4, \mathrm{v} / \mathrm{v})$ to give the title 5-demethoxy-6-ketofumagillol 6 as a colorless oil (60 mg, 50\% yield). IR (neat) $v_{\max } \mathrm{cm}^{-1}: 3851,3733,3647,2917$, $1716,1558,1455,1386,1253,1139,909,836,457 \mathrm{~cm}^{-1} .{ }^{1} \mathrm{H}-\mathrm{NMR}$ $\left(500 \mathrm{MHz}, \mathrm{CDCl}_{3}\right) \delta: 5.15(\mathrm{t}, J=7.3 \mathrm{~Hz}, 1 \mathrm{H}), 2.94(\mathrm{~d}, J=4.3 \mathrm{~Hz}, 1 \mathrm{H}), 2.75$ $(\mathrm{d}, J=4.3 \mathrm{~Hz}, 1 \mathrm{H}), 2.74-2.67(\mathrm{~m}, 3 \mathrm{H}), 2.58(\mathrm{ddd}, J=14.4,4.7,1.7 \mathrm{~Hz}, 1 \mathrm{H})$, $2.44-2.40(\mathrm{~m}, 2 \mathrm{H}), 2.12(\mathrm{~m}, 1 \mathrm{H}), 2.02-1.98(\mathrm{~m}, 1 \mathrm{H}), 1.93-1.89(\mathrm{~m}, 1 \mathrm{H})$, $1.83(\mathrm{dd}, J=10.7,4.7 \mathrm{~Hz}, 1 \mathrm{H}), 1.75(\mathrm{~s}, 3 \mathrm{H}), 1.65(\mathrm{~s}, 3 \mathrm{H}), 1.26(\mathrm{~s}, 3 \mathrm{H}) .{ }^{13} \mathrm{C}-$ NMR $\left(\mathrm{CDCl}_{3}, 100 \mathrm{MHz}\right) \delta$ : 208.36, 135.14, 118.06, 62.21, 60.07, 58.45, 51.66, 47.61, 40.93, 38.63, 32.26, 27.50, 25.76, 17.98, 13.84. HR-MS $m / z$ : Calcd for $\mathrm{C}_{15} \mathrm{H}_{22} \mathrm{O}_{3}\left(\mathrm{M}^{+}\right), 250.1569$. Found: 250.1560 .

$(3 R, 4 R, 6 R)-4-[(2 R, 3 R)-2-M e t h y l-3-(3-m e t h y l-b u t-2-e n y l)-o x i r a n y l]-1-$ oxa-spiro[2.5]octan-6-ol (1) To a pre-cooled $\left(-78^{\circ} \mathrm{C}\right)$, stirred solution of 5-demethoxy-6-ketofumagillol $6(24 \mathrm{mg}, 0.096 \mathrm{mmol})$ in dry tetrahydrofuran $(2 \mathrm{ml})$ a $1.0 \mathrm{M} \mathrm{L}$-selectride solution in tetrahydrofuran $(0.144 \mathrm{ml}$, $0.144 \mathrm{mmol}$ ) was added dropwise by syringe pump under $\mathrm{N}_{2}$ atmosphere. The reaction mixture was stirred at $-78^{\circ} \mathrm{C}$ for $1 \mathrm{~h}$, and quenched by addition of methanol $(5 \mathrm{ml})$ and saturated $\mathrm{NH}_{4} \mathrm{Cl}$ solution $(30 \mathrm{ml})$. The mixture was extracted with ethyl acetate $(100 \mathrm{ml})$, washed with water $(60 \mathrm{ml})$, dried over anhydrous $\mathrm{Na}_{2} \mathrm{SO}_{4}$, and filtered and concentrated in vacuo to leave an oil residue which was purified by column chromatography on silica gel with ethyl acetate/ $n$-hexane $(1: 2, \mathrm{v} / \mathrm{v})$ as elution solvent to afford the first major fraction, the title compound 5-demethoxyfumagillol 1, as a colorless oil (20 mg, 83\%). IR (neat) $v_{\max } \mathrm{cm}^{-1}: 3851,3733,3647,3444,2922,1698$,
1683, 1652, 1558, 1540, 1507, 1456, 1385, 986, 445. ${ }^{1} \mathrm{H}-\mathrm{NMR}(400 \mathrm{MHz}$, $\left.\mathrm{CDCl}_{3}\right) \delta: 5.18(\mathrm{t}, J=7.5 \mathrm{~Hz}, 1 \mathrm{H}), 4.31(\mathrm{t}, J=2.5 \mathrm{~Hz}, 1 \mathrm{H}), 2.87(\mathrm{~d}$, $J=4.3 \mathrm{~Hz}, 1 \mathrm{H}), 2.71(\mathrm{dd}, J=7.0,6.1 \mathrm{~Hz}, 1 \mathrm{H}), 2.53(\mathrm{~d}, J=4.3 \mathrm{~Hz}, 1 \mathrm{H}), 2.39$ $(\mathrm{m}, 1 \mathrm{H}), 2.24(\mathrm{td}, J=13.4,4.8 \mathrm{~Hz}, 1 \mathrm{H}), 2.12(\mathrm{~m}, 1 \mathrm{H}), 2.01-1.94(\mathrm{~m}, 2 \mathrm{H})$, $1.91-1.84(\mathrm{~m}, 2 \mathrm{H}), 1.81-1.78(\mathrm{~m}, 1 \mathrm{H}), 1.75(\mathrm{~s}, 3 \mathrm{H}), 1.65(\mathrm{~s}, 3 \mathrm{H}), 1.15(\mathrm{~s}$, $3 \mathrm{H}), 1.09$ (dt, $J=13.8,3.1 \mathrm{~Hz}, 1 \mathrm{H}) .{ }^{13} \mathrm{C}-\mathrm{NMR}\left(\mathrm{CDCl}_{3}, 100 \mathrm{MHz}\right) \delta: 134.90$, $118.35,65.66,64.19,60.39,59.64,51.10,42.14,33.16,30.20,29.17,27.60$, 25.75, 18.00, 13.67. HR-MS $m / z$ : Calcd for $\mathrm{C}_{15} \mathrm{H}_{24} \mathrm{O}_{3}\left(\mathrm{M}^{+}\right), 252.1725$. Found: 252.1739 .

6-epi-5-Demethoxyfumagillol (1') Further purification of the minor fraction gave the title stereoisomer product $\mathbf{1}^{\prime}$ as a colorless oil ( $\left.3 \mathrm{mg}, 13 \%\right)$. IR (neat) $v_{\max } \mathrm{cm}^{-1}: 3851,3733,3647,3445,2918,1698,1683,1652,1558$, $1540,1507,1456,1071,491,418 .{ }^{1} \mathrm{H}-\mathrm{NMR}\left(\mathrm{CDCl}_{3}, 400 \mathrm{MHz}\right) \delta: 5.16(\mathrm{t}$, $J=7.5 \mathrm{~Hz}, 1 \mathrm{H}), 3.76(\mathrm{~m}, 1 \mathrm{H}), 2.88(\mathrm{~d}, J=4.3 \mathrm{~Hz}, 1 \mathrm{H}), 2.67(\mathrm{dd}, J=7.2$, $5.9 \mathrm{~Hz}, 1 \mathrm{H}), 2.58(\mathrm{~d}, J=4.3 \mathrm{~Hz}, 1 \mathrm{H}), 2.41(\mathrm{~m}, 1 \mathrm{H}), 2.22-2.18(\mathrm{~m}, 1 \mathrm{H})$, $2.14-2.08(\mathrm{~m}, 1 \mathrm{H}), 2.20(\mathrm{~m}, 1 \mathrm{H}), 1.89-1.83(\mathrm{~m}, 2 \mathrm{H}), 1.80-1.77(\mathrm{~m}, 1 \mathrm{H})$, $1.74(\mathrm{~s}, 3 \mathrm{H}), 1.70-1.67(\mathrm{~m}, 1 \mathrm{H}), 1.65(\mathrm{~s}, 3 \mathrm{H}), 1.42(\mathrm{dd}, J=12.8,3.4 \mathrm{~Hz}$, $1 \mathrm{H}), 1.29(\mathrm{dt}, J=14.0,3.4 \mathrm{~Hz}, 1 \mathrm{H}), 1.18(\mathrm{~s}, 3 \mathrm{H}) .{ }^{13} \mathrm{C}$ NMR $\left(\mathrm{CDCl}_{3}\right.$, $100 \mathrm{MHz}) \delta: 135.48,118.62,70.07,64.60,60.69,58.82,50.92,47.19$, 35.57, 33.27, 33.01, 27.96, 26.15, 18.40, 13.99. HR-MS $\mathrm{m} / \mathrm{z}$ Calcd for $\mathrm{C}_{15} \mathrm{H}_{24} \mathrm{O}_{3}\left(\mathrm{M}^{+}\right), 252.1725$. Found: 252.1773 .

5-Demethoxy-6-O-(chloroacetylcarbamoyl)fumagillol (7) To a solution of 5-demethoxyfumagillol $1(100 \mathrm{mg}, 0.39 \mathrm{mmol})$ in dry dichloromethane $(10 \mathrm{ml})$ was added dimethylaminopyridine $(50 \mathrm{mg}, 0.40 \mathrm{mmol})$ and chloroacetyl isocyanate $(95 \mathrm{mg}, 0.79 \mathrm{mmol})$. After stirring for $1 \mathrm{~h}$, the reaction mixture was quenched with saturated $\mathrm{NH}_{4} \mathrm{Cl}(5 \mathrm{ml})$ and extracted with dichloromethane $(30 \mathrm{ml})$. The organic layer was washed with water $(10 \mathrm{ml})$, and brine $(10 \mathrm{ml})$, respectively, dried with anhydrous $\mathrm{Na}_{2} \mathrm{SO}_{4}$, and concentrated by evaporation under reduced pressure to leave an oil which was purified by column chromatography on $\mathrm{SiO}_{2}$ with ethyl acetate/n-hexane $(1: 4$, $\mathrm{v} / \mathrm{v})$ to give the title compound as an off-white foam ( $102 \mathrm{mg}, 70.3 \%$ yield). IR $v_{\max } \mathrm{cm}^{-1}: 3280,2960,1790,1755,1725,1490,1380,1230,1190 .{ }^{1} \mathrm{H}-$ NMR $\left(400 \mathrm{MHz}, \mathrm{CDCl}_{3}\right) \delta: 1.30(\mathrm{~m}, 1 \mathrm{H}), 1.16(\mathrm{~s}, 3 \mathrm{H}), 1.65(\mathrm{~s}, 3 \mathrm{H}), 1.75(\mathrm{~s}$, $3 \mathrm{H}), 2.41-1.81(\mathrm{~m}, 8 \mathrm{H}), 2.60(\mathrm{~d}, J=4.2 \mathrm{~Hz}, 1 \mathrm{H}), 2.66(\mathrm{~m}, 1 \mathrm{H}), 2.92(\mathrm{~d}$, $J=4.2 \mathrm{~Hz}, 1 \mathrm{H}), 4.49(\mathrm{~m}, 1 \mathrm{H}), 5.16(\mathrm{t}, J=7.3 \mathrm{~Hz}, 1 \mathrm{H}), 7.83$ (br s, $1 \mathrm{H}) .{ }^{13} \mathrm{C}-$ NMR $\left(100 \mathrm{MHz}, \mathrm{CDCl}_{3}\right) \delta: 19.3,22.6,24.8,25.3,25.8,39.6,49.6,57.5$, 59.6, 67.3, 125.8, 133.2, 136.0, 157.3. HR-MS $m / z$ Calcd for $\mathrm{C}_{18} \mathrm{H}_{26} \mathrm{ClNO}_{5}$ $\left(\mathrm{M}^{+}\right), 371.1573$. Found: 371.1525 .

Anti-proliferation Activities The anti-proliferation activities of fumagillol (3) and 5-demethoxyfumagillol derivatives (1) and 7 were evaluated as follows. Endothelial cells from calf pulmonary artery (CPAE, ATCC CRL$209)$ were plated on 96 -well microtiter plates $\left(2 \times 10^{4}\right.$ cells $\left./ \mathrm{ml}\right)$ and incubated with MEM medium supplemented with $10 \%$ fetal bovine serum and $100 \mu \mathrm{g} / \mathrm{ml}$ endothelial cell growth supplement (ECGS). Murine leukemia L5178Y cells were plated on 96-well microtiter plates $\left(2 \times 10^{4} \mathrm{cell} / \mathrm{ml}\right)$ and incubated with RPMI 1640 medium supplemented with $10 \%$ fetal bovine serum. CPAE cells and the other cells were incubated for 4 and $3 \mathrm{~d}$ at $37^{\circ} \mathrm{C}$ in a $5 \% \mathrm{CO}_{2}$ incubator, respectively. The anti-proliferation activities were colorimetrically measured by SRB (CPAE cells) or MTT (L5178Y cells) method and the $\mathrm{IC}_{50}$ values were estimated by Probits method $\left(\mathrm{Pharm} / \mathrm{PCS}^{\mathrm{R}}\right)$. The biological data for fumagillol and 5-demethoxyfumagillol derivatives are summarized in Table 1 .

Acknowledgements We gratefully acknowledge generous financial support from the Korean Ministry of Health and Welfare (HMP-00-CD-020004). We thank Dr. S. S. Lee for his helpful discussion.

\section{References}

1) Billington D. C., Drug Des. Discov., 8, 3-35 (1991).

2) Folkman J., N. Eng. J. Med., 285, 1182-1186 (1971).

3) Hanson F. R., Eble T. E., J. Bacteriol., 58, 527-529 (1949).

4) McCorkindale N. J., Sime J. G., Proc. Chem. Soc., 1961, 331 (1961).

5) Ingber D., Fujita T., Kishimoto S., Sudo K., Kanamara T., Brem H., Folkman J., Nature (London), 348, 555-557 (1990).

6) Folkman J., Ingber D. E., Cancer Biol., 3, 89-96 (1992).

7) Ingber D. E., Cancer Biol., 3, 57-63 (1992).

8) Folkman J., J. Natl. Cancer Inst., 82, 4 -6 (1990).

9) Taylor S., Folkman J., Nature (London), 297, 307-312 (1982)

10) Folkman J., Adv. Cancer Res., 43, 175-203 (1985).

11) Stadler W. M., Kuzel T., Shapiro C., Sosman J., Clark J., Vogelzang N. J., J. Clin. Oncol., 17, 2541-2545 (1999).

12) Zgodzinski W., Wallner G., Dabrowski A., Pol. J. Pharmacol., 51, $455-462$ (1999)

13) Moore J. D., Dezube J., Gill P., Zhou X. J., Acosta E. P., Sommadossi J. 
P., Cancer Chem., 46, 173-179 (2000).

14) Kruger E. A., Figg W. D., Expert Opin. Investig. Drugs, 9, 13831396 (2000).

15) Choi N. S., Lee S. J., Ahn S. K., Chun H. S., Hong R. K., Kim J. W., Lee H. W., Moon S. K., Hong C. I., W. O. Patent 99/59987 (1999).

16) Tarbell D. S., Hoffman P., Al-Kazani R., Page G. A., Ross J. M., Vogt H. R., Wargotz B., J. Am. Chem. Soc., 77, 5610-5617 (1955).

17) Molander G. A., Hahn G., J. Org. Chem., 51, 1135-1138 (1986).
18) Folkman J., Ingber D. E., Ann. Surg., 206, 374-383 (1987).

19) Oikawa T., Hirotani K., Nakamura O., Shudo K., Iwaguchi T., Cancer Lett., 48, 157-162 (1989).

20) Langer R., Brem H., Falterman K., Klein M., Folkman J., Science, 193, 70-72 (1976).

21) Marui S., Itoh F., Kozai Y., Sudo K., Kishimoto S., Chem. Pharm. Bull., 40, 96-101 (1992).

22) Still W., Kahn M., Mitra A., J. Org. Chem., 43, 2923-2925 (1978). 